\title{
AN ANALYSIS OF FIGURATIVE LANGUAGE AND MORAL VALUE IN ROAR SONG BY KATY PERRY
}

\author{
Bejo Sutrisno ${ }^{1}$ \\ bejo@stibaiecjakarta.ac.id \\ Sekolah Tinggi Bahasa Asing IEC Jakarta \\ Lestari \\ lestari@gmail.com \\ Sekolah Tinggi Bahasa Asing IEC Jakarta
}

Sutrisno, B. and Lestari. (2021). An Analysis of Figurative Language and Moral Value in Roar Song by Katy Perry . Journal of English Language and literature, 6(2), 21-30. doi: 10.37110/jell.v6i2.125

Received: 02-07-2021

Accepted: 25-08-2021

Published:03-09-2021

\begin{abstract}
This research is aimed to analyze the figurative languages used in Roar song by Katy Perry. Objectives of the study: (1) to find out the figurative languages used in Roar song by Katy Perry, (2) to find out the meaning of figurative language used in Roar song by Katy Perry, and (3) to find out the moral value messages of the song lyrics. Based on the objective of the study, the researcher uses descriptive qualitative method in collecting the data. From the data analysis, the researcher found out of figurative language appeared in Roar song by Katy Perry. They are Metaphor, Personification, Simile, Paradox, Irony, Alliteration, Onomatopoeia and Hyperbole. It can be implied that figurative language is always used in song lyrics. In Roar song lyrics, there can find moral value massages that can be learned in by the figurative language shown in this song. That is trusting ourself, never doubt to ourself and believe that we have power to refuse some of bad thins comes to our life such as bullying and toxic relationship.
\end{abstract}

Keywords: Figurative Language, Moral Value.

\section{INTRODUCTION}

Language is something important in human life. Language is used to express someone's feelings or emotion and also to express their ideas, their thoughts and their imaginations. It can be spoken or written. Spoken language can be found in the song, speech, and conversation. Some people confess their feeling with other through song, for example when someone wants to show his or her love to another one, they can express it by singing a song. Through song lyrics someone could convey his voice to many people, so that people can know his feelings. Currently a lot of songs lyric could express our feelings, such as songs with the theme of love, social, political, and others .

Through song people can convey their voice to many people. Song is one of literature work and song is the act or art of singing. Songs as piece of music with words that are sung which have a function to express the thoughts and feeling. Song has two elements that is lyrics and music. Song lyric usually uses both literal or figurative language.

According to Sapir, language is as purely human and non instinctive method of

${ }^{1}$ Corresponding Author 
communicating ideas, emotion and desire by means of system of voluntarily produced symbol. Furhtermore, as Hamby states that language is a system of sounds, words, and pattern used by human to thoughts and feeling. (Sapir, 2007).

Lyric is a soul of the song. It could present what the song purpose. The lyric mode exist in literature when the author induces the reader to know, from within, the virtual experience of a more or less particularized consciousness. When this aim constitutes the predominant organizing principal of a poem, we say that the poem is a lyric.( Williams, 1984)

Figurative language is a language using figures of speech (a way of saying one thing or meaning another). It is associated with lyric of the song uses figurative language. There are many types of figurative language such as: metaphor, simile, symbols, hyperbole, irony, etc. Figurative language uses in lyrics are make the massages of the lyrics become clear for the reader. The previous research was conducted by Khadijah Arifah (2016), she conducted her research entitled Figurative Language Analysis in Five John Legend's songs. Her research found that the use of figurative languages in John Legend's songs showed that hyperbole is the most figurative language used like in the lyric "My head's underwater but I'm breathing fine".

In song ROAR by Katy Perry, She describes her feelings and thoughts. that lyric reveals a feeling when she was struggling and trying to survive even that surrounding her are trying to brought her down she tried to up and she was prove that she could stand up as herself. The writer is interested to analyze the song lyrics of Katy Perry because in this lyrics there is a lot of figurative language shown in this song. There are so many expression from singer that are imagine about condition and situation which singer felt.

According to the description above, the writer studies figurative language used in lyric of song ROAR of Katy Perry. Besides, found out some kinds of figurative language and it true meaning used in this song the writer also analysis the moral value shown in this song. In this analysis, the writer chooses figurative language and moral value in the song lyrics as a research. The writer can find out the figurative language which is interesting to be understood deeply and also learn moral value of this song. So, the writer chooses "The Analysis of Figurative Language and moral value in ROAR song by Katy Perry" as the title of this thesis.

Not only to find the figurative language in this song but the writer tough that in the Roar song lyrics there are spirit of inner power of human to fight the situation that human faces. Nowadays a lot of bullying case and toxic relationship in life. By hearing this song the writer though the lyrics in this song was has a moral value to be learn for someone to against the situation of human life. In this paper the writer would analyze the lyrics if it has a moral value in the lyrics of Roar song by Katy Perry. The objectives of this research are (1) to find out the figurative languages used in Roar song lyrics by Katy Perry; (2) to elaborate the connotative meanings of the lyrics in Roar song by Katy Perry; and (3) to know the moral value in Roar song lyrics by Katy Perry.

\section{REVIEW OF LITERATURE}

In this chapter the writer explains about the approach and theories relating to the study which are being discussed. Those theories are important and useful for the writer to conduct the analysis. They are to support and strengthen the writer's thoughts and also to prove what the writer believe is true. In this chapter the writer would like to make easy understanding meaning of figurative language by using some of theories which are related to the literature review.

\section{Figurative Language}

Figurative language is language that has figurative meaning or language using figures of speech, it cannot be taken literally (or should not be taken literally only). Figurative language is a language which has figurative meaning and incorporates the speaker's desires to touch the emotions, to cause shock and to persuade into action (Peter, 2012) . 
According to Keraf (2009), it can be stated that "Language style or figurative language is the way of giving expression through a special language which shows the soul and the writer personality (Language user). A good language style has to certain three elements, three are: sincerity, respectful, and attractive.

Ruth Miller and Robert A. Greenberg (1982 : 66) defines figurative language that is means of indirect statement that says one thing in term of another. The effectiveness of such usage can vary widely. It can seem foolish if it is not especially appropriate. However, as often as not the effect can be a liveliness of expression that manage to press very closely to the essence of an object or idea while also conveying a strong sense of the speaker's attitudes and feelings. For the poets, whose tendency is to see and think figuratively, the used of figurative language is virtually incapale.

From the explanation above, it is considered that figurative language deals with language which use figure of speech and language cannot be taken literary only and it is used to express the inner feeling of the writer and it has three elements of the writer, they are : sincerity, respectful and attractive.

\section{Kinds of Figurative language}

\section{a. Metaphor}

Metaphor is a figurative language used in an imaginative to describe something in order to say that between the two things are the same qualities and it is function to the description more powerful without using sign posting. Metaphor is figurative speech, which is compare one thing to another directly (Peter, 2002).

J. Lawrence, cited in Gillian Lazar (1996: 43), the word metaphor derives from the Greek 'meta' which expresses change, and 'pherein' which has meaning 'to carry'. In other words, metaphor involves a 'carrying across' of meaning from one object to another. Metaphor can also be said as a statement that one thing is something else which is in literal sense, it is not. This saying "time is money" which is very common in the daily conversation is a result of metaphor. Most people might lack of notice that metaphor, or even any other kinds of figurative language, has become a part of daily spoken language.

Patrick Griffiths (2006) states that Metaphor belongs to both an explicit and implicit comparison. When a figure of speech contains words such as like or as, it makes a comparison explicitly. Omitting the connectives develops a comparison in metaphor to be a hidden comparison or an implicit one. Recognizing metaphor just by paying attention to the presence or absence of a connective is no longer such an accurate way, even though it is the most frequently done. One thing should be kept in mind is metaphor implies a comparison between two unlike things which have one or more points in common by speaking of one thing in terms of another or by identifying one thing with another (Kreuzer, 1960).

An example of metaphor expression is taken from a novel by Frank McCourt entitled Angela's Ashes A Memoir, "Your mind is your house and if you fill it with rubbish from the cinemas it will not rot in your head. You might be poor, your shoes might be broken, but your mind is a palace." Through those sentences, McCourt first compares mind with house which has been known that mind and house are two different things, but in this context, they have one thing in common. Both mind and house are a place used to be filled with "rubbish from cinemas." Then, he compares mind with palace. They are identified as two unlike things, but similar as a place which has everything precise inside of them. McCourt might be poor, but he could think of his mind as a palace which surely has riches beyond belief to him.

\section{b. Simile}

Simile is comparison which formally develop a similarity between two things using as, seems, like, than, or other equivalent construction. Actually both simile and metaphor are comparing things that are essentially difference. 
But the usage of those equivalent contractions may become the only dissimilarity between simile and metaphor or we can conclude that the comparison is made explicitly in simile but it is just implicitly in metaphor (Hooper: 143).

\section{c. Personification}

The most familiar kinds of comparison is personification---that is, speaking of something that is not human as if it had human abilities and human reactions (Masruri, 2012). Personification consists in giving the attributes of human being to an animal, an object, or a concept. It is really a subtype of metaphor, and implied comparison in which the figurative term of the comparison is always a human being.

According to Christopher Russel Reaske (2002:101)that personification is the process of assigning human characteristics to non human objects, abstactions or ideas. Attributing personal form to such non human object and ideas is a standart rhetorical device in poetry.

Example:

\section{The moon smiles at us The trees are waving to the tiger}

\section{d. Hyperbole}

Hyperbole is simply exaggeration but exaggeration in the series of the truth and it used with a variety of effects. It maybe humorous or grave fanciful or restrained, convincing or unconvincing.

Steven Croft and Hellen Cross (2000: 179) states that hyperbole is a figure of speech that is in international exaggeration for emphasis or humorous effect. When someone says, "if the river is dry, I am able to fill it with tears" or says, "I will eat you if you do not go right away", he is adding emphasis to what he really means.

Example:

She rushed out the room in floods of tears $=$ crying a lot

Let's have dinner, I am straving = very hungry

When she was in Paris, she spent a ton of money $=$ a lot of money

\section{e. Irony}

According to Edgar V. Roberts and Robert Zweig (2001), irony is a mode of ambiguous or indirect expression. It is natural to human beings who are aware of possibilities and complexities in life.

Irony is a result from the contrast between the actual meaning of a word or statement and the suggestion of another meaning. The intended implications are often actually a mockery of what is literally being stated.

Example:

At a difficult moment, and act of kindness makes things worse, and someone says, "well, that's a lot of better, isn't it?"

Someone says to his friend, "you are very slim" whereas the fact is that his friend is very fat.

\section{f. Onomatopoeia}

Onomatopoeia is the use of words to imitate sounds. Words such as bang, pop, crunch, meow, snap, babble, squeal, or thrump are example of onomatopoeia. Writers use onomatopoeia to give their intended meaning double emphasis. Readers get meaning from what the printed word stand for and from the sound of the word. In the poem "Crossing", Phillip uses onomatopoeia when he describes the "bell clang" at the railroad crossing (Russel, 2002:24).

\section{g. Metonymy}

Metonymy is a form of figurative language that involves the substitution of one word to another. Metonymy is device of letting one word stand for another closely related word. Metonymy is also rhetorical strategy of describing something indirectly by referring to thing around it, as describing someone's clothing in order to characterize the individual. For instance, the pen is mightier than the sword and her voice is full of money (Kennedy, 1983).

Paul (2011) stated, metonymy is based on transfer within a single conceptual domain. 
Then, Dennis (1996) stated that metonymy is a name or descriptive term which is transferred to some objects different form, but analogous to, that is properly applicable.

Example : " we called American Government as the white house ".

\section{h. Paradox}

Paradox is a result when a poet presents a pair of ideas, words, images, or attitudes which are, or appear to be, self-contradictory (Masruri, 2011).

Paradox is figure of speech that links apparently contradictory terms in a single statement that is, in fact, true. However, while it may appear that these opposite are contradictory, paradox often underlines the possibility that both may be true. Paradox is implied in poetry primarily as a device of emphasis, drawing attention to something. Paradox is kind of figurative language, which contains real contradictory thing with the fact.

\section{i. Idiom}

An idiom is a phrase that people say that is commonly accepted as having a different meaning that the individual words may lead you to believe. McCarthy and O'Dell in their book " English idiom in use " stated that 'Idiom are expression which have a meaning that is not obvious from the individual words'. It means that the meaning of idiom is not literal meanings, but they have non literal meanings. The best way to understand idiom meaning are looking at the content. For example, ' drive somebody' is and idiom meaning make somebody angry or frustrated (Mc Carthy, 2003).

\section{j. Alliteration}

Alliteration is the repetition of the same or similar sounds at the beginning of words (Gerard Manley).

\section{Moral Value}

In a social life, there is a value of life. Moral can be described as the human acts, feeling, speech, that associated with the things which could reflect whether good or bad behavior in society in life.

Moral Value are things that cannot be constrained for person have. However, it gives some benefits to ourselves. By having moral values we can avoid something that other people dislike. Also we can avoid bad judgment from people around us (Margaret, 2004).

According to Stephen Badu-Yeboah (2013: 1617), Moral Value are abstract principles ( or absolute truth, metaphysical codes, or spiritual deposits ) whose substense cannot be pointed to, but whose existential manifestation is able to be known and aknowledge.

Moral value are set of principles that helps us evaluate what is good and what is bad.Moral value are a set of some of precious value which help us in becoming a good human being. These values involve a lot of factors like morality, respecting others, helping others, loving others,etc (Sehba, 2017)

Based on the definition above the writer agree that moral value affect to our life,

Good moral value will bring us the good person and could avoid some of problem in our life due to we could avoid something bad that dislike by other people. Having a good moral value give us a lot of benefit in our human life.

\section{METHOD}

Qualitative approach is used in this research to emphasize the qualities of entities, proccesses and meanings that are not experimentally examined or measured in terms of quantity, amount, intensity or frequency (Uncolin and Denzin, 2012).

A technique of collecting data is used to describe a process of preparing and collecting data. To find out the solution of the problem discussion in this research, the writer needs some data. Primary source is a material directly related to the topic. It serves as an original source of information about the topic. These materials include the song lyrics of Roar by Katy Perry from the original cassette or CD or webssite. The writer takes these lyrics as the primary source that is take from website. Secondary source materials can be in journals, and also website. The secondary source is 
taken from some books, journals, and e-books which related to the song lyrics.

\section{FINDING AND DISCUSSION}

The writer discusses the analysis of the types of figurative language and its meaning in the lyric of " ROAR “song by Katy Perry. Figurative languages are found in each of the lyric line. Figurative language marked with underline type. In this explanation, the writer explains about the message that want to shown from this song. And the least one, while all findings are given in the following table in this chapter.

Before analyzing figurative language in this lyrics, the writer want to code first the kinds of figurative language to conduct the research, such as below :

1) Metraphore (Mtr)

2) Simile (Sme)

3) Personification (Psn)

4) Hyperbole $(\mathrm{Hbp})$

5) Irony (Iry)

6) Onomatopoeia (Oma)

7) Metonymy (Mny)

8) Paradox (Prx)

9) Idiom (Idm)

In this research, lyrics of Roar song is become the primary data to be analyzed. And here is the lyrics of Roar song by Katy Perry :

I used to bite my tongue and hold my breath

Scared to rock the boat and make a mess

So I sat quietly

Agreed politely

I guess that I forgot I had a choice

I let you push me past the breaking point

I stood for nothing

So I fell for everything

You held me down, but I got up

Already brushing off the dust

You hear my voice, You hear that sound

Like thunder gonna shake the ground
You held me down, but I got up

Get ready 'cause I've had enough

I see it all, I see it now

I got the eye of the tiger, a fighter, dancing through the fire

Cause I am a champion and

You're gonna hear me ROAR

Louder, louder than a lion

Cause I am a champion and

You're gonna hear me ROAR

Oh oh oh oh oh oh

You're gonna hear me roar

Now I'm floating like a butterfly

Stinging like a bee I earned my stripes

I went from zero, to my own hero

You held me down, but I got up

Already brushing off the dust

You hear my voice, You hear that sound

Like thunder gonna shake the ground

You held me down, but I got up

Get ready 'cause I've had enough

I see it all, I see it now

I got the eye of the tiger, a fighter, dancing through the fire

Cause I am a champion and

You're gonna hear me ROAR

Louder, louder than a lion

Cause I am a champion and

You're gonna hear me ROAR

Oh oh oh oh oh oh

You're gonna hear me roar

Roar-or, roar-or, roar-or

I got the eye of the tiger, a fighter, dancing through the fire

Cause I am a champion and

You're gonna hear me ROAR

Louder, louder than a lion

Cause I am a champion and 
You're gonna hear me ROAR

Oh oh oh oh oh oh

You're gonna hear me roar

The writer though that this song was describes about Perry relationship with her boyfriend and she wants to shows that she could end up the toxic relationship. Through this song the writer wants to prove about the inner power to fight the toxic relationship. The writer though that this song has a figurative language that show some of moral value to fight toxic relationship.

To make the discussion clear, the writer will analyzed figurative language in Roar song by Katy Perry by analyzing line by line of lyrics of this song.

All the lyrics in Roar song by Katty Perry was analyzed in the table below.

Table 1: Figurative language and meaning in song lyrics Roar

\begin{tabular}{|c|c|c|c|}
\hline No & Phrase & $\begin{array}{l}\text { Figurative } \\
\text { language }\end{array}$ & Meaning \\
\hline 1 & $\begin{array}{l}\text { I used to bite my tongue and hold } \\
\text { my breath }\end{array}$ & $\begin{array}{l}\text { Idiom } \\
\text { Hyperbole }\end{array}$ & Waiting for something bad happen \\
\hline 2 & $\begin{array}{l}\text { Scared to rock the boat and make } \\
\text { a mess! }\end{array}$ & $\begin{array}{l}\text { Idiom } \\
\text { Hyperbole }\end{array}$ & $\begin{array}{l}\text { Will not doing something bacause of it } \\
\text { will disturb the situation }\end{array}$ \\
\hline 3 & so I sat quietly, agreed politely & Metonymy & Agree in everything happen \\
\hline 4 & I guess that I forgot I had a choice & Alliteration & She doesn't has a choice \\
\hline 5 & $\begin{array}{l}\text { I let you push me past the } \\
\text { breaking point }\end{array}$ & Idiom & $\begin{array}{l}\text { Her boyfriend take control in everything } \\
\text { they do. }\end{array}$ \\
\hline 6 & $\begin{array}{l}\text { I stood for nothing, so I fell for } \\
\text { everything }\end{array}$ & Alliteration & She can't do anything \\
\hline 7 & $\begin{array}{l}\text { You held me down, but I got up } \\
\text { (hey!) }\end{array}$ & Paradox & Nobody could brought her down \\
\hline 8 & Already brushing off the dust & Idiom & She was ready to standup for herself \\
\hline 9 & $\begin{array}{l}\text { You hear my voice, you hear that } \\
\text { sound }\end{array}$ & Alliteration & $\begin{array}{l}\text { she has a power that everyone could feel } \\
\text { it }\end{array}$ \\
\hline & $\begin{array}{l}\text { like thunder, gonna shake the } \\
\text { ground }\end{array}$ & $\begin{array}{l}\text { Simile } \\
\text { Hyperbole }\end{array}$ & $\begin{array}{l}\text { She wants to shows that she was powerful, } \\
\text { She was stronger than before. }\end{array}$ \\
\hline & get ready cause I have enough & Idiom & $\begin{array}{l}\text { she doesnt have anything but in this line } \\
\text { she wants to shows that she was ready to } \\
\text { standup by herse }\end{array}$ \\
\hline & I see it now, I see it all & Alliteration & $\begin{array}{l}\text { She wants to shows that she understand } \\
\text { the situation now and she doesnt want to } \\
\text { be like her in past. }\end{array}$ \\
\hline 13 & I got the eye of tiger, fighter & $\begin{array}{l}\text { Metaphor } \\
\text { Personification } \\
\text { Idiom }\end{array}$ & $\begin{array}{l}\text { Metaphor : when she was compare her } \\
\text { eyes and the tiger eyes. It also could be } \\
\text { personification due to she assigning her } \\
\text { eyes (part of human) with eye of the tiger } \\
\text { (not part of human ). } \\
\text { Idiom : it is not the real meaning, actually } \\
\text { Perry doesn't has the tiger eyes. It means } \\
\text { that she was stronger than she at the past, } \\
\text { she could see if there is something bad }\end{array}$ \\
\hline
\end{tabular}




\begin{tabular}{|c|c|c|c|}
\hline & & & $\begin{array}{l}\text { happen in front of her, she could focus on } \\
\text { everything happen now. }\end{array}$ \\
\hline 14 & Dancing to the fire & Hyperbole & $\begin{array}{l}\text { whatever problem appear she was ready to } \\
\text { fight for that problem. She has a power to } \\
\text { fight with the situation }\end{array}$ \\
\hline 15 & $\begin{array}{l}\text { Cause I am of the champion and } \\
\text { you're gonna hear me roar }\end{array}$ & Idiom & $\begin{array}{l}\text { she wants to said is nobody could } \\
\text { brounght her down anymore. }\end{array}$ \\
\hline 16 & Oooh..oooh..hoooo..hoo & Onomatopoeia & $\begin{array}{l}\text { she wants to said is nobody could } \\
\text { brounght her down anymore. }\end{array}$ \\
\hline 17 & You're gonna hear me roar & $\begin{array}{l}\text { Alliteration } \\
\text { Metaphor } \\
\text { Idiom }\end{array}$ & $\begin{array}{l}\text { Perry has a strong power like the tiger she } \\
\text { could attack the enemy }\end{array}$ \\
\hline 18 & Now,I am floating like a butterfly & Simile & $\begin{array}{l}\text { she could enjoy everything happen now } \\
\text { and she could receipt the reality of her life. }\end{array}$ \\
\hline 19 & I went from zero, to my own hero & Paradox & $\begin{array}{l}\text { she could move on and could bears and } \\
\text { change the situation. }\end{array}$ \\
\hline 20 & Louder, louder than the lion & $\begin{array}{l}\text { Alliteration } \\
\text { Metaphor }\end{array}$ & $\begin{array}{l}\text { she could fight with her enemy or } \\
\text { everything that her face. } \\
\text { She wants to shows that she is powerful }\end{array}$ \\
\hline 21 & Roar, roar, roaaaaarrrr & Onomatopoeia & Sound of lion \\
\hline
\end{tabular}

\section{DISCUSSION}

Based on the findings above, it could be discussed as follows.

\section{The Figurative language and the meaning found in the song lyrics.}

Data 1:

"I used to bite my tongue and hold my breath "

In this line of figurative language that it could be found two figurative languages, there are idiom and hyperbole.

McCarthy and O'Dell in their book ' English idiom in use " stated that 'Idiom are expression which have a meaning that is not obvious from the individual words'. It means that the. Because we couldn't holding the breath, it only could to feel but couldn't touched. She was not actually bite her tongue because when she bite her tongue she would died, It is impossible to do because when she bite her tongue she would hurts and could be passed out (Mc Carthy, M. \& O’Dell , F, 2003).
Hyperbole : hyperbole, according to last chapter it was described as the figurative language that shown exaggeration words. We couldn't really bite our tongue and hold our breath. It is an impossible things to do.

In this line Perry would said that she was waiting for something bad happen.

Data 2 :

"Scared to rock the boat and make a mess! “

This line is shown both idiom and hyperbole.

Idiom : we couldn't really rock the boat due to boat is always bigger than us. And she doesn't really rock the boat.

Hyperbole : we can't shake the boat in our life due to boat is always bigger than us. It is exaggeration.

This line She would saying that she wouldn't do something to disturb the situation and doesn't has the capability to change the situation. 
Journal of English Language and literature

Volume 6, Issue 2, September 2021

Data 3 :

" so I sat quietly, agreed politely "

This line is metonymy, according to Kennedy Metonymy is a form of figurative language that involves the substitution of one word to another. Metonymy is device of letting one word stand for another closely related word. Metonymy is also rhetorical strategy of describing something indirectly by referring to thing around it, as describing someone's clothing in order to characterize the individual. In this line Perry shows that the her condition was in the situation that she can't refuse the situation. She was agree in everything happened due to her boyfriend took over everything in their relationship (Kennedy, 1983).

In this line she wants to say that she was agree everything happen in her relationship.

\section{Data 4 :}

\section{"I guess that I forgot I had a choice "}

This line shown alliteration, Gerard Manley stated alliteration is the repetition of the same or similar sounds at the beginning of words. In this line Perry using same begining sound in word I.

This line meaning is she wants to shows that she didn't any choice.

\section{Data 5 :}

"I let you push me past the breaking point"

This line also an idiom, it is not real meaning. This line she wants to shows that her boyfriend took control averything in their ralationship.

\section{Data 6 :}

\section{"I stood for nothing, so I fell for everything}

In this line was an alliteration. In this line it shows the same sound in the beginning I and the ending -thing. This line meaning was she didn't do anything.

Data 7 :

"You held me down, but I got up (hey!)"
p-ISSN 2540-8216, e-ISSN 2654-3745

https://journal.stibaiec-jakarta/ojs/index.php/jell

This line is paradox, Paradox is figure of speech that links apparently contradictory terms in a single statement that is, in fact, true. However, while it may appear that these opposite are contradictory, paradox often underlines the possibility that both may be true. it is show a contradiction situation between down and up.

In this line Perry shows her power that no body could drop her down.

Data 8 :

"Already brushing off the dust"

This is idiom, it is not the real meaning that she realy brush the dust from her body it is meaning that she was ready to fight with everything burden her. And also it has meaning that she was ready to stand for herself.

Data 9:

"You hear my voice, you hear that sound "

This line is alliteration. This line shows the same beginning in word you hear.

Perry shows that she has a power that everyone could feel it.

Data 10 :

"like thunder, gonna shake the ground"

This word is simile and hyperbole.

Simile is comparison which formally develop a similarity between two things using as, seems, like, than, or other equivalent construction stated by James H Pickering and Jeffrey D. Hooper.

Simile : when she compare her voice (previous lyric) and the thunder using word "like" it shows that she has a power that could shake other .

Hyperbole : it is exaggeration. The writer never see by her eyes that there is sound like thunder that could shake the earth, it will be earquake if there is sound like that and all of us will not be saved.

Between previous lyric and this if we are compare it could be personification

"You hear my voice, you hear that sound. Like thunder gonna shake the ground " 
It shows personification because Perry assigning her voice (human) with the thunder voice (not part of a human ).

In this line Perry wants to shows that she was powerful, She was stronger than before.

\section{Data 11:}

"Get ready "cause i had enough"

This line is shows Idiom. It is not the real meaning due to actually she doesnt have anything but in this line she wants to shows that she was ready to standup by herself.

\section{Data 12 :}

\section{"I see it now, I see it all"}

It line shows a alliteration because it is using words " $i$ see" in a repetitive sequence. She wants to shows that she understand the situation now and she doesnt want to be like her in past.

Data 13 :

"I got the eye of the tiger, fighter"

It shows methapore / personification and Idiom.

According to Peter (2002), Metaphor is a figurative language used in an imaginative to describe something in order to say that between the two things are the same qualities and it is function to the description more powerful without using sign posting. Metaphor is figurative speech, which is compare one thing to another directly.

Methapore : when she was compare her eyes and the tiger eyes. It also could be personification due to she assigning her eyes (part of human) with eye of the tiger (not part of human ).

Idiom : it is not the real meaning, actually Perry doesn't have the tiger eyes. It means that she was strongger than she at the past, she could see if there is someting bad happen infront of her, she could focus on everything happen now.

Data 14 :

"Dancing through the fire"
This line shows hyperbole and idiom. Because we cant actually dance on the fire it will burn and hurt us or it would make us die. Her meaning is whatever problem appear she was ready to fight for that problem. She has a power to fight with the situation.

It is also an idiom because she wants to tells that she is strong. She also could enjoy the situation.

Data 15 :

" 'Cause I am a champion, and you're gonna hear me roar"

This line is shows Idiom. It is not the real meaning that she wants to said is nobody could brounght her down anymore.

Data 16 :

"ooooh...oooh..hooo..hooo"

This line shows the onomatopoeia. Christopher Russel (2002:24) said Onomatopoeia is the use of words to imitate sounds. Words such as bang, pop, crunch, meow, snap, babble, squeal, or thrump are example of onomatopoeia. Writers use onomatopoeia to give their intended meaning double emphasis. Readers get meaning from what the printed word stand for and from the sound of the word. In the poem "Crossing", Phillip uses onomatopoeia when he describes the "bell clang" at the railroad crossing.

And this line shows sounds of the tiger.

Data 17 :

"You're gonna hear me roar "

This line shows alliteration. In this line is shows the end of -'re.

And in this line Perry also show methapore, that she comparing her voice with the tiger voice.

This also show an idiom because of human can't roar like the tiger. This line meaning is Perry has a strong power like the tiger she could attack the enemy.

Data 18 : 
Journal of English Language and literature

Volume 6, Issue 2, September 2021

\section{"Now i'm floating like a butterfly"}

This line was shown a simile. Due to Perry use the word like to compare her and the butterfly. It meaning that she could enjoy everything happen now and she could receipt the reality of her life.

Data 19 :

“ I went from zero, to my own hero “

This line tells us about paradox. It is the situation contradiction from zero was the condition she was empty she was weak at the past then she could past everything and become herself as a hero, the condition that she was powerful. It is means that she could move on and could bears and change the situation.

Data 20 :

"Louder, louder than the lion "

This line show us about alliteration and methapore.

Alliteration : when she beggining sound " $\mathrm{el}$ (1) “.

Methapore : in this line Perry was compare between her voice and the lion voice.

It is meaning is that she could fight with her enemy or everything that her face.

She wants to shows that she is powerful.

Data 21 :

"Roar, roar, roaaaaarrrr"

This is shows an onomatopoeia. Its a sound of the lion. It is shows her power.

\section{The Moral Value found in the song}

While writing this thesis, the writer found moral value massages that could be learned by the lyrics in Roar song by Katy Perry. According to Sehba (2017) moral value are set of principles that helps us evaluate what is good and what is bad.Moral value are a set of some of precious value which help us in becoming a good human being. These values involve a lot of factors like morality, respecting others, helping others, loving others,etc. The writer found moral value about how to respecting ourself and believe in our abilty. For example while
p-ISSN 2540-8216, e-ISSN 2654-3745

https://journal.stibaiec-jakarta/ojs/index.php/jell

someone face toxic relationship or bullying case. This song gave us the spirit through pass it.

The moral value that shown in the lyrics was an inner power of the human, we can see that the lyrics tells us about how to trust in our power we could fight with everything we faced. There is a power in a human to defense ourself. We could decide to be strong or weak.

Based on the findings above the writer found the relationship between the figurative language and the moral value, that is some of the human didn't realzed that we have the power inside of us. This lyrics have powerful spirit to fight against the problem that we faced.

The lyrics have related massages of inner power that human have to trust in ourself that we could end up the problem we faced by our power. In this case, the writer found in this song that the song has the spirit to fight against the toxic relationship. No body could force us to be that they want in our life. We could decide what we want to be, what we want to choose or what we want to believe. Just because we love someone doesn't mean that he or she could decide everything in us. What we need to know is we are strong enough to be ourself. If we think that the relationship is unhealthy we could choose to end up the relationship or if there is something terrible we found in our life we could choose to decide what we want.

In other case, if we found bullying in our life we have to believe that everything is in our control. The bullying could happen only when we led it to be. In the reality we have the power inside of us to stop it, believe in ourself that we have the ability to fight with everything surround us. Love ourself and believe in ourself, this is the key to fight the situation we faced.

By the explanation above, the writer found the moral value sliped in the lyrics of the Roar song by Katty Perry is never doubt to ourself that we are so worthy and we are loveable. We have our own power to face the problem we faced.

\section{CONCLUSIONS}


From the findings and discussion above the writer found out some of the figurative language in the lyrics of song Roar by Katy Perry. The figurative languages uses in the lyrics to beautify the song and make the listener more understand about the meaning and messages of the song.

In Roar song by Katy Perry there are found some of the figurative languages, see the table bellow that could show what are the figurative language found out in the Roar song that idiom (7);

\section{REFERENCES}

Arifah, K. 2016. Thesis: Figurative Language Analysis in Five John Legend's Song. English Education. Jurnal Tadris Bahasa Inggris Vol. 10 No.1. p-ISSN 2086-6003. Malang: Maulana Malik Ibrahim State University. Retrieved on August 5, 2018.

Badhu, S. and Yeboah. 2013. Proof of the Existence of God: An Evidentiary Truth Based on Science, Moral Value, and Philology. Bloomington : WestBow press.pp. 16-17

Croft, S and Cross, H. 2000. Literature, Criticism, and Style. Oxford: Oxford University Press, p.179

Dennis. 1996. Language and diction in Linguistic.Barkeley. University of California.

Frost, R. 2001. Introduction to Linguistic. London: Cook Voices

Gibbs, R. H. (1999). About Us: MITECS. Dipetik August 10, 2015, dari MITECS Web Site: http://ai.ato.ms/MITECS/Entry/gibbs

Griffths, P. (2006). An Introduction to English Semantics and Pragmatics.Edinburgh: Edinburgh University Press Ltd.

Kennedy, XJ.1983. Litterature : An introduction to fiction, poetry and drama.Boston: Little Brown Company.

Keraf, G. 2009. Diksi dan Gaya Bahasa. Jakarta: Gramedia Pustaka Utama
Hyperbole (4); Metonymy (1); Alliteration (5); Similw (2); Metaphor (3); Personification (1); Onomatopoia (1); and Paradox (1).

Figurative languages use in the lyrics of Roar song has meaning to encourage the listener. Through the figurative language in the lyrics the singer wants to tells the listener to standup for our self, this song has moral value to trust in our self, believe in our self and never let other to pushed us down.

Kreuzer, J.R. (1960). Studies in Prose Writing. New York: Holt, Rineheart and Winston, Inc.

Lazar, G. (1996). Using Figurative Language to Expand Students' Vocabulary. ELT Journal, 50,43

Lincolin and Denzin. 2000. The SAGE Handbook of Qualitative Research.

Margareth, M. (2014). An analysis of moral value in Kungfu Panda movie by John Wayne.

Masruri, M.Z. (2011) An Analysis of Figurative language on The Lyrics of Westlife selected song.

Mc Carthy, M. \& O’Dell , F. 2003.English Idiom in Use. Cambridge; Cambridge University Press.

Miller, R and Robert, A. Greenberg. 1982. Poetry: An Introduction. Basingstoke: Palgrave Macmillan Publisher.

Peter.2002. Figurative Language and Semantics. Boston : Little Brown and Company.

Sapir. 2007. Language, Sexuality, and Power; Studies in International Sociolinguistics. Oxford University Press.

Sehba. 2017. paragraph of moral value and its meaning. India.

Williams, A. 1984. Prophetic Strain: The Greater English Lyric in the Eighteen Century. Chicago: University of Chicago Press 